\title{
PENGARUH PROMOSI DAN SALURAN DISTRIBUSI TERHADAP VOLUME PENJUALAN PRODUK SURVEI PADA SENTRA UMKM DI KABUPATEN BANDUNNG
}

\section{THE INFLUENCE OF PROMOTION AND DISTRIBUTION CHANNELS TO SALES VOLUME SURVEY ON SMES CENTERS IN THE DISTRICTS OF BANDUNG}

\author{
Fera Regi Ardiansyah
}

Dr. Ir. Herman S. Soegoto, MBA.

Fakultas Pascasarjana Universitas Komputer Indonesia (UNIKOM)

\begin{abstract}
ABSTRAK
Promosi adalah suatu komunikasi informasi penjual dan pembeli yang bertujuan untuk merubah sikap dan tingkah laku pembeli. Saluran distribusi adalah sekumpulan organisasi atau institusi yang saling bergantung membantu membuat suatu produk atau jasa yang dijual kepada konsumen akhir melalui penjual atau perantara. Sedangkan volume penjualan jumlah yang dipandang dari hubungan biaya dalam perusahaan dapat memperkirakan target unit penjualan untuk memperoleh laba yang ditentukan
\end{abstract}

Tujuan penelitian ini adalah untuk mengetahui bagaimana pengaruh kegiatan promosi dan saluran distribusi secara bersama-sama terhadap volume penjualan pada UMKM di kabupaten Bandung.

Metode penelitian ini melalui pendekatan kuantitatif. Responden dalam penelitian ini adalah pelaku sekaligus pemilik UMKM di kabupaten Bandung dengan jumlah 100 responden.

Hipotesis yang diajukan dalam penelitian ini yaitu terdapat pengaruh antara promosi dan saluran distribusi terhadap volume penjualan.

Hasil pengujian hipotesis menunjukkan bahwa ketiga hipotesis alternatif $\left(\mathrm{H}_{\mathrm{a}}\right)$ yang diajukan dalam penelitian ini diterima, dan menolak hipotesis nol (Ho). Beberapa kesimpulan penelitian dapat dirumuskan sebagai berikut :

Berdasarkan pengujian persamaan regresi diperoleh $\mathrm{Y}=17,049+0,511 \mathrm{X}_{1}+0,356 \mathrm{X}_{2}$, persamaan regresi tersebut dapat diartikan bahwa setiap kenaikan satu satuan variabel tingkat promosi dan saluran distribusi akan meningkatkan variabel volume penjualan sebesar 0,511 satuan tingkat promosi dan 0,356 satuan saluran distribusi pada konstanta 17,049.

Pengujian hipotesis menunjukan bahwa $\mathrm{F}_{\text {hitung }}$ sebesar 70,728 sedangkan $\mathrm{F}_{\text {tabel }}$ dengan dk pembilang $=1 \mathrm{dan} \mathrm{dk}$ penyebut $=\mathrm{dk}=100-2-1=97$ dengan taraf kesalahan 5\% harga $\mathrm{F}$ tabel ditemukan adalah 3,95 (interpolasi). Dengan demikian harga $F_{\text {hitung }}$ lebih besar dari harga $F_{\text {tabel }}\left(F_{\text {hitung }}>F_{\text {tabel }}\right)$. Hal ini menunjukan bahwa Ha diterima dan Ho ditolak.

Hal ini telah berimplikasi pada tingkat peningkatan volume penjualan yang secara positif dipengaruhi oleh dua faktor determinan secara bersama-sama, yaitu promosi dan saluran distribusi dimana tingkat volume penjualan produk menjadi sasaran terwujudnya UMKM yang sehat.

Kata Kunci : Promosi, Saluran Distribusi, Volume Penjualan 


\section{ABSTRACT}

Progress of a company or a business is an exceptional acquired company or business. The election proper promotion and diversification of products when the product cycle is very crucial to determine a forward or resignation of a business. No escape from it all, the level of sales that occurred is a key point or indicator of a company can survive or not in the business world.

This research method through a quantitative approach. respondents in this study were the perpetrators and owner of SMEs in Bandung district with 100 respondents.

The hypothesis of this research that there is influence between promotion and distribution channels to sales volume.

The test results indicate that the third hypothesis alternative hypothesis $(\mathrm{Ha})$ is proposed in this study received, and rejecting the null hypothesis (Ho). Some research conclusions can be formulated as follows:

Based on testing regression equation $Y=17.049+0,511 X 1+0,356 X 2$, the regression equation can be interpreted that each increase of one unit of a variable level of promotion and distribution channels will increase the variable unit sales volume amounted to 0.511 and 0.356 levels promotion unit at constant 17.049 distribution channels.

Hypothesis testing showed that Fcount 70.728 while Ftable with numerator $d f=1$ and denominator $d f=d f=100-2-1$ standard error $=97$ with $5 \%$ price tables found was $3.95 \mathrm{~F}$ (interpolation). Thus Fcount price greater than the price Ftabel (Fcount > F table). This shows that Ha Ho accepted and rejected.

This has implications for the level of increase in sales volumes positively affected by two determinant factors together, namely the promotion and distribution channels where the level of product sales volume was subjected to the realization of healthy SMEs.

Keywords: Promotion, Distribution Channel, Volume Sales 


\section{PENDAHULUAN}

\section{Latar Belakang Masalah}

Perusahaan yang berorientasi kepada pasar harus memikirkan bagaimana cara mempengaruhi konsumen, khususnya pembeli potensial agar bersedia membeli produk yang dihasilkan. Untuk dapat bertahan dalam keadaan yang peka terhadap perubahan yang penuh persaingan saat ini, sebuah perusahaan pertama-tama harus menentukan apa yang dapat di jual dan strategi apa yang dapat meningkatkan pelanggan. Salah satu bauran pemasaran yang akan dikaji dalam penelitian ini adalah yang berhubungan dengan aktivitas promosi yang memegang peranan penting dalam usahanya meningkatkan volume penjualan melalui suatu proses promosi dan saluran distribusi.

Promosi adalah salah satu kegiatan marketing yang salah satu fungsinya untuk meningkatkan hasil penjualan, baik secara langsung maupun secara tidak langsung. Oleh sebab itu promosi sangat penting bagi perusahaan, dalam usaha untuk memasarkan dan memperkenalkan hasil produk perusahaan. Upaya untuk memperkenalkan produk kepada konsumen merupakan awal dari kegiatan promosi. Adapun definisi dari kegiatan promosi tersebut menurut Basu Swastha (2008:237) adalah : Arus Informasi atau persuasi satu arah yang dibuat untuk mengarahkan seseorang atau organsiasi kepada tindakan yang menciptakan pertukaran dalam pemasaran. Jadi, promosi merupakan salah satu aspek yang diaktakan dalam manajemen pemasaran dan sering dikatakan sebagai proses berlanjut. Ini disebabkan karena promosi dapat menimbulkan rangkaian kegiatan selanjutnya dari perusahaan. Adapun saluran distribusi merupakan aktivitas pemasaran yang berusaha menyebarkan informasi, mempengaruhi, dan mengingatkan pasar sasaran atas perusahaan dan produknya agar bersedia menerima, membeli dan loyal pada produk yang ditawarkan perusahaan yang bersangkutan (Tjiptono 2008:219).

Dari definisi di atas dapat disimpulkan bahwa saluran distribusi merupakan serangkaian organisasi yang terkait dalam semua kegiatan yang digunakan untuk menyalurkan produk. Perusahaan dapat menggunakan lembaga atau perantara untuk dapat menyalurkan produknya kepada konsumen akhir. Tujuan dari saluran distribusi adalah untuk mencapai pasar-pasar tertentu. Jadi, pasar merupakan tujuan

\section{Jurnal Ilmiah Magister Managemen UNIKOM}

akhir dari kegiatan saluran distribusi. Sedangkan definisi penjualan menurut Mulyadi (2008:202) yaitu penjualan merupakan kegiatan yang dilakukan oleh penjual dalam menjual barang atau jasa dengan harapan akan memperoleh laba dari adanya transaksitransaksi tersebut dan penjualan dapat diartikan sebagai pengalihan atau pemindahan hak kepemilikan atas barang atau jasa dari pihak penjual ke pembeli.

Menurut Swastha dan Irawan (2008:182) pengukuran volume penjualan dapat dilakukan dengan dua cara, yaitu tercapainya target penjualan, dimana target penjualan yang diukur berdasarkan unit produk yang terjual. Dan peningkatan jumlah keuntungan, dimana peningkata keuntungan di dapat dari jumlah Usaha Mikro Kecil dan Menengah (UMKM) sebagai salah satu komponen dalam industri nasional, mempunyai peranan yang sangat penting dalam perekonomian nasional, penyerapan tenaga kerja, pemerataan distribusi hasil-hasil pembangunan, dan penanggulangan kemiskinan. Usaha Mikro Kecil dan Menengah (UMKM) umumnya memiliki keunggulan dalam bidang yang memanfaatkan sumberdaya alam dan padat karya, misalnya pertanian tanaman pangan, perkebunan, peternakan, perikanan, perdagangan dan restoran.

Salah satu masalah besar yang dihadapi dalam pemberdayaan UMKM di Kabupaten Bandung adalah rendahnya akses UMKM terhadap pasar. Secara konseptual diketahui bahwa empat unsur yang mempengaruhi keberhasilan suatu perusahaan dalam berkompetisi adalah a) produk, b) harga, c) tempat/lokasi dan, d) promosi. Keempat faktor strategis ini saling terkait dalam meningkatkan fungsi pemasaran. Dalam era keterbukaan ini dimana batas-batas ruang sudah mulai ditinggalkan peran faktor promosi yang terkait dengan ruang yang sangat luas mulai memperlihatkan pengaruh dominannya. Dominasi faktor promosi diindikasikan dari luasnya penyebaran suatu jenis produk yang ada kalanya dapat menekan pengaruh ketiga faktor lainnya.

\section{Perumusan Masalah}

Berdasarkan identifikasi permasalahan diatas, maka penulis merumuskan permasalahan dalam penelitian ini sebagai berikut : 
1. Bagaimana pengaruh kegiatan promosi terhadap volume penjualan pada UMKM di Kabupaten Bandung

2. Bagaimana pengaruh saluran distribusi terhadap volume penjualan pada UMKM di Kabupaten Bandung

3. Bagaimana pengaruh kegiatan promosi dan saluran distribusi secara bersama sama terhadap volume penjualan pada UMKM di Kabupaten Bandung

\section{Tujuan Penelitian}

Adapun tujuan dilakukan penelitian ini adalah :

1. Untuk mengetahui bagaimana pengaruh kegiatan promosi terhadap volume penjualan pada UMKM di kabupaten Bandung.

2. Untuk mengetahui bagaimana pengaruh saluran distribusi terhadap volume penjualan pada UMKM di kabupaten Bandung.

3. Untuk mengetahui bagaimana pengaruh kegiatan promosi dan saluran distribusi secara bersama-sama terhadap volume penjualan pada UMKM di kabupaten Bandung.

\section{KAJIAN PUSTAKA}

\section{Promosi}

a. Definisi Promosi

Menurut Fandy Tjiptono (2002:233) bahwa : Promosi adalah suatu bentuk komunikasi pemasaran. Komunikasi pemasaran adalah aktivitas pemasaran yang berusaha menyebarkan informasi, mempengaruhi atau membujuk, dan atau mengingatkan pasar sasaran atas perusahaan dan produknya agar bersedia menerima, membeli, dan loyal pada produk yang ditawarkan perusahaan yang bersangkutan.

Berdasarkan pendapat tersebut maka dapat ditarik kesimpulan bahwa promosi adalah usaha-usaha yang dilakukan oleh perusahaan untuk mempengaruhi konsumen dengan jalan menyediakan informasi yang bersifat persuasi untuk mempengaruhi pasar dan memperoleh respons.

\section{b. Indikator Promosi}

1. Penawaran khusus

2. Periklanan

3. Endorsement/dukungan
4. User trials/uji pelanggan

5. Direct mailing

6. Posters

7. Free Gifts/Hadiah gratis

8. Undian

9. Kerjasama

\section{Saluran Distribusi}

\section{a. Definisi Saluran Distribusi}

Menurut Tjiptono

(2008:187) menyebutkan bahwa : Saluran distribusi adalah rute atau rangkaian perantara, baik yang dikelola pemasar maupun yang independen, dalam menyampaikan barang dari produsen ke konsumen.

Dari definisi di atas dapat ditarik kesimpulan bahwa saluran distribusi merupakan suatu sistem yang aktivitasnya bertujuan untuk menggerakkan atau menyalurkan produk dari produsen kepada konsumen. Tujuan saluran distrbusi adalah untuk mencapai pasar tertentu yang merupakan tujuan akhir kegiatan saluran distribusi.

\section{b. Indikator Saluran Distribusi}
1. Retailing (Pengecer)
2. Wholesaling (Agen atau Distributor)
3. Mail order
4. Internet
5. Penjualan langsung
6. Peer to peer

\section{Volume Penjualan}

\section{a. Definisi Volume Penjualan}

Volume penjualan meruapakan jumlah total yang dihasilkan dari kegiatan penjualan barang. Semakin besar jumlah penjualan yang dihasilkan perusahaan, semakin besar kemungkinan laba yang akan dihasilkan perusahaan. Oleh karena itu volume penjualan merupakan salah satu hal penting yang harus dievaluasi untuk kemungkinan perusahaan agar tidak rugi. Jadi volume penjualan yang menguntungkan harus menjadi tujuan utama perusahaan dan bukannya untuk kepentingan volume penjualan itu sendiri.

Sedangkan pengertian volume penjualan menurut Basu Swastha $(2008 ; 197)$ yaitu suatu studi mendalam dalam penjualan bersih dari laporan rugi laba perusahaan (laporan operasional). 


\section{b. Indikator volume penjualan}

1. Target Penjualan

2. Peningkatan laba

3. Penunjang Pertumbuhan perusahaan

\section{Hipotesis Penelitian}

Berkaitan dengan permasalahan yang diteliti, maka hipotesis penelitian yang diajukan dalam penelitian ini dapat dirumuskan sebagai berikut :

1. Terdapat pengaruh kegiatan promosi terhadap volume penjualan pada UMKM di Kabupaten Bandung.

2. Terdapat pengaruh saluran distribusi terhadap volume penjualan pada UMKM di Kabupaten Bandung.

3. Promosi dan saluran distribusi secara bersama-sama berpengaruh terhadap volume penjualan pada UMKM di Kabupaten Bandung.

\section{METODOLOGI PENELITIAN}

\section{Metode yang Digunakan}

Metode yang digunakan dalam penelitian ini adalah deskriptif analisis dengan menggunakan teknik analisis korelasi. Metode ini memberi gambaran tentang variabel-variabel yang ditemukan, sekaligus menyelidiki hubungan antara variabel, karena itu metode ini akan mengungkapkan data faktual bedasarkan informasi yang ditemukan.

\section{Operasionalisasi Variabel}

Tabel Operasionalisasi Variabel

\begin{tabular}{|c|c|c|}
\hline Variabel & Indikator & Skala \\
\hline $\begin{array}{l}\text { Promosi : } \\
(X 1)\end{array}$ & $\begin{array}{ll}\text { 1. } & \text { Penawaran khusus } \\
\text { 2. } & \text { Periklanan } \\
\text { 3. } & \text { Endorsement/dukungan } \\
\text { 4. } & \text { User trials/uji pelanggan } \\
\text { 5. } & \text { Direct mailing } \\
\text { 6. } & \text { Posters } \\
\text { 7. } & \text { Free Gifts/Hadiah gratis } \\
\text { 8. } & \text { Undian } \\
\text { 9. } & \text { Kerjasama }\end{array}$ & Ordinal \\
\hline $\begin{array}{c}\text { Saluran } \\
\text { Distribusi : } \\
\text { (X2) }\end{array}$ & $\begin{array}{ll}\text { 1. } & \text { Retailing (Pengecer) } \\
\text { 2. } & \text { Wholesaling (Agen atau } \\
\text { 3. } & \text { Distributor) } \\
\text { 4. } & \text { Mail order } \\
\text { 5. } & \text { Penjualan langsung } \\
\text { 6. } & \text { Peer to peer }\end{array}$ & Ordinal \\
\hline $\begin{array}{c}\text { Volume } \\
\text { Penjualan } \\
\text { (Y) }\end{array}$ & $\begin{array}{ll}\text { 1. } & \text { Target Penjualan } \\
\text { 2. } & \text { Peningkatan laba } \\
\text { 3. } & \begin{array}{l}\text { Penunjang Pertumbuhan } \\
\text { perusahaan }\end{array}\end{array}$ & Ordinal \\
\hline
\end{tabular}

Jurnal Ilmiah Magister Managemen UNIKOM

\section{Cara Penentuan Data/Informasi}

Teknik sampling yang digunakan dalam penelitian ini yaitu Simple Random Sampling sedangkan teknik pengambilan sample menggunakan rumus dari Taro Yamane atau slovin (dalam Riduwan, 2007:65).

$$
n=\frac{N}{N \cdot d^{2}+1}
$$

Dalam penelitian ini penulis menggunakan langkahlangkah sebagai berikut dalam menentukan data yang akan dipergunakan

1. Penelitian Lapangan (Field Research). Adapun data dan informasi dikumpulkan dengan cara sebagai berikut :
a. Kuisioner
b. Wawancara

2. Studi literatur/kepustakaan (Library Research)

\section{HASIL PENELITIAN DAN PEMBAHASAN}

\section{Analisis Deskriftif Karakteristik Responden : Berdasarkan Jenis Kelamin}

Pelaku UMKM yang berjenis kelamin laki-laki lebih banyak di bandingkan perempuan, hal ini merupakan bentuk tanggung jawab sebagai kepala keluarga yang berkewajiban untuk menafkahi istri dan anaknya.

\section{Berdasarkan Usia}

Mayoritas pelaku UMKM di Kabupaten bandung berada pada rentang usia $30-40$ tahun. Hal ini menunjukan bahwa pelaku UMKM di kota Bandung sebagaian besar berada pada usia puncak produktif dengan tingkat emosional yang cenderung stabil.

\section{Berdasarkan Tingkat Pendidikan}

Mayoritas pelaku UMKM di kabupaten Bandung adalah lulusan SMA, hal ini terjadi di mungkinkan karena desakan ekonomi dimana untuk melanjutkan kuliah mereka tidak memiliki biaya sehingga lebih memilih untuk berwira swasta. Sedangkan untuk lulusan Diploma I - III mereka lebih memilih bekerja pada perusahaan besar dengan mengincar jabatan tertentu.

\section{Berdasarkan Pekerjaan Sebelumnya}

Pelaku UMKM di Kabupaten Bandung berasal dari kalangan wiraswata, berdasarkan interview yang telah dilakukan ternyata mereka kebanyakan meneruskan usaha yang telah dirintis oleh orang tua 
mereka, atau ada beberapa responden yang mengaku memindahkan tempat usaha warisan orang tua nya ke Kabupaten Bandung dengan harapan mendapatkan peluang pasar yang lebih luas.

\section{Analisis Deskriftif Variabel Penelitian :}

\section{Variabel Promosi}

Berdasarkan observasi yang telah dilakukan diperoleh bahwa hasil penelitian menunjukkan bahwa rentangan skor variabel promosi berada antara 55 sampai dengan 90, skor rata-rata sebesar 71,78, simpangan baku atau standar deviasi sebesar 8,162, median sebesar 72,00. Variabel promosi diketahui melalui indikator, yaitu: penawaran khusus, periklanan, endorsement/dukungan, user trials/uji pelanggan, direct mailing, posters, free gifts/hadiah gratis, undian dan kerjasama. Indikator ini memuat 20 item pertanyaan yang harus dijawab oleh pelaku UMKM di kabupaten Bandung sebagai responden penelitian. Setelah ke 20 item pertanyaan disebar kepada 100 responden, maka hasil pengelolaannya adalah skor actual $=7178$ apabila dibandingkan sengan skor ideal $10.000=(5 \times 20 \times 100)$, maka akan didapatkan skor kecenderungan sebesar 71,78\%. Berdasarkan tetapan kriteria, maka variable promosi termasuk dalam kaegori baik.

\section{Tabel Distribusi Frekuensi Variabel Promosi Statistics}

Promosi
\begin{tabular}{|l|r|}
\hline N $\quad$ Valid & 100 \\
Mean & 0 \\
Median & 71.78 \\
Std. Deviation & 72.00 \\
Variance & 8.162 \\
Minimum & 66.618 \\
Maximum & 55 \\
Sum & 90 \\
\hline
\end{tabular}

\section{Saluran Distribusi}

Berdasarkan observasi yang telah dilakukan diperoleh bahwa hasil penelitian menunjukkan bahwa rentangan skor variabel promosi berada antara 46 sampai dengan 86, skor rata-rata sebesar 74,08, simpangan baku atau standar deviasi sebesar 7,262, median sebesar 73,50. Variabel saluran distribusi diketahui melalui indikator, yaitu: retailing (pengecer),
」IM M UN I K T M

Jurnal Ilmiah Magister Managemen UNIKOM

wholesaling (agen atau distributor), mail order, internet, penjualan langsung dan peer to peer. Indikator ini memuat 20 item pertanyaan yang harus dijawab oleh pelaku UMKM di kabupaten Bandung sebagai responden penelitian. Setelah ke 20 item pertanyaan disebar kepada 100 responden, maka hasil pengelolaannya adalah Skor actual $=7408$ apabila dibandingkan sengan skor ideal $10.000=(5 \times 20 \mathrm{x}$ 100), maka akan didapatkan skor kecenderungan sebesar $74,08 \%$. Berdasarkan tetapan kriteria, maka variable promosi termasuk dalam kaegori baik.

\section{Tabel Distribusi Frekuensi Variabel Saluran Distribusi Statistics}

Saluran Distribusi
\begin{tabular}{|l|r|}
\hline \multicolumn{1}{|c|}{ Valid } & 100 \\
\multicolumn{1}{|c}{ Missing } & 0 \\
Mean & 74.08 \\
Median & 73.50 \\
Std. Deviation & 7.262 \\
Variance & 52.741 \\
Minimum & 46 \\
Maximum & 86 \\
Sum & 7408 \\
\hline
\end{tabular}

\section{Volume Penjualan}

Berdasarkan observasi yang telah dilakukan diperoleh bahwa hasil penelitian menunjukkan bahwa rentangan skor variabel promosi berada antara 58 sampai dengan 90, skor rata-rata sebesar 78,13, simpangan baku atau standar deviasi sebesar 6,167, median sebesar 79,00. Variabel volume penjualan diketahui melalui indikator, yaitu: target penjualan, peningkatan laba dan penunjang pertumbuhan perusahaan.

Indikator ini memuat 20 item pertanyaan yang harus dijawab oleh pelaku UMKM di kabupaten Bandung sebagai responden penelitian. Setelah ke20 item pertanyaan disebar kepada 100 responden, maka hasil pengelolaannya adalah Skor actual $=7813$ apabila dibandingkan sengan Skor ideal $10.000=(5 \times 20 \mathrm{x}$ 100), maka akan didapatkan skor kecenderungan sebesar 78,13\%. Berdasarkan tetapan kriteria, maka variable promosi termasuk dalam kategori baik. 


\section{BIDANG MANAJEMEN}

\section{Tabel Distribusi Frekuensi \\ Variabel Volume Penjualan}

\section{Statistics}

Volume Penjualan
\begin{tabular}{|l|r|}
\hline \multicolumn{1}{|c|}{ Valid } & 100 \\
\multicolumn{1}{|c|}{ Missing } & 0 \\
Mean & 78.13 \\
Median & 79.00 \\
Std. Deviation & 6.167 \\
Variance & 38.033 \\
Minimum & 58 \\
Maximum & 90 \\
Sum & 7813 \\
\hline
\end{tabular}

\section{Pengujian Hipotesis}

\section{Pengaruh Promosi $\left(\mathrm{X}_{1}\right)$ Terhadap Volume Penjualan (Y)}

Uji kecendrungan dilakukan untuk mendeskripsikan kondisi nyata yang berkembang sebagai fenomena dilapangan yang dilihat berdasarkan item dalam angket penelitian untuk promosi terhadap volume enjualan. Untuk besarnya nilai korelasi variabel $\mathrm{X}_{1}$ terhadap $\mathrm{Y}$ diperoleh melaui perhitungan SPSS Versi 17.0 adalah 0,670 pada taraf signifikasi 0,05 . sedangkan determinasinya sebesar 0,418 atau bisa dikatakan variabel $\mathrm{Y}$ dipengaruhi oleh variabel $\mathrm{X}_{1}$ sebesar $41,8 \%$ sebagaimana terlihat pada tabel dibawah ini :

Tabel Hasil Perhitungan Determinasi Korelasi Variabel X1 Terhadap Y

Model Summary ${ }^{\mathrm{b}}$

\begin{tabular}{|l|l|l|l|l|}
\hline Model & $\mathrm{R}$ & R Square & $\begin{array}{l}\text { Adjusted R } \\
\text { Square }\end{array}$ & $\begin{array}{l}\text { Std. Error of the } \\
\text { Estimate }\end{array}$ \\
\hline 1 & $.647^{\mathrm{a}}$ & .418 & .412 & 4.728 \\
\hline
\end{tabular}

a. Predictors: (Constant), Promosi

b. Dependent Variable: Volume Penjualan

Sedangkan nilai regresi variabel $\mathrm{X}_{1}$ terhadap $\mathrm{Y}$ yang didapatkan dari hasil perhitungan dapat dilihat dalam persamaan sebagai berikut :
ل I M M UN IK TM

Jurnal Ilmiah Magister Managemen UNIKOM

$\mathrm{Y}=43,053+0,489 \mathrm{X}_{1}$. Artinya perubahan pada variabel $\mathrm{X}_{1}$ akan diikuti oleh perubahan pada variabel Y secara positif.

Tabel Resume Regresi Variabel $\mathrm{X}_{1}$ Terhadap Y

Coefficients $^{\mathrm{a}}$

\begin{tabular}{|c|r|r|r|r|r|}
\hline \multirow{2}{*}{ Model } & \multicolumn{2}{|c|}{$\begin{array}{c}\text { Unstandardized } \\
\text { Coefficients }\end{array}$} & $\begin{array}{c}\text { Standardized } \\
\text { Coefficients }\end{array}$ & \multirow{2}{*}{$\mathrm{t}$} & \multirow{2}{*}{ Sig. } \\
\cline { 2 - 5 } & \multicolumn{1}{c|}{$\mathrm{B}$} & Std. Error & \multicolumn{1}{|c|}{ Beta } & & \\
\hline 1 (Constant) & 43.053 & 4.205 & & 10.238 & .000 \\
Promosi & .489 & .058 & .647 & 8.394 & .000 \\
\hline
\end{tabular}

a. Dependent Variable: Volume Penjualan

Hipotesis pertama yang diajukan adalah hipotesis alternatif $(\mathrm{Ha})$ : promosi berpengaruh secara signifikan terhadap volume penjualan atau dengan kata lain $\mathrm{Ha}=$ koefisien regresi signifikan.

Berdasarkan perbandingan $t_{\text {hitung }}$ dan $t_{\text {tabel, }}$ diketahui bahwa $t_{\text {hitung }}$ adalah 8,394 sedangkan $t_{\text {tabel }}$ dengan tingkat signifikasi 5\% dan $\mathrm{df}=\mathrm{N}-2 ; 100-2$ $=98$ didapatkan angka 1,990 (interpolasi) perbandingan antara $t_{\text {hitung }}$ dengan $t_{\text {tabel }}$ dapat dikatakan bahwa $t_{\text {hitung }}$ lebih besar dari $t_{\text {tabel. }}$ Artinya Ha diterima dan Ho ditolak atau dapat dikatakan bahwa Promosi benar-benar berpengaruh secara signifikan terhadap volume penjualan.

\section{Pengaruh Saluran Distribusi $\left(X_{2}\right)$ terhadap Volume Penjualan (Y)}

Hasil perhitungan dengan menggunakan SPSS 17.0 menunjukan bahwa Saluran Distribusi dapat mempengaruhi Volume Penjualan dengan besaran nilai 0,371 . nilai korelasi ini mempunyai determinasi sebesar 0,138 atau dapat dikatakan volume penjualan dipengaruhi oleh Saluran Distribusi sebesar 0,138 atau $13,8 \%$. Sebagaimana terdapat pada tabel berikut ini.

Tabel Hasil Perhitungan Determinasi Korelasi Variabel $\mathrm{X}_{2}$ terhadap $\mathrm{Y}$

Model Summary ${ }^{b}$

\begin{tabular}{|r|r|r|r|r|}
\hline Model & R & R Square & $\begin{array}{c}\text { Adjusted R } \\
\text { Square }\end{array}$ & $\begin{array}{c}\text { Std. Error } \\
\text { of the } \\
\text { Estimate }\end{array}$ \\
\hline 1 & $.371^{\mathrm{a}}$ & .138 & .129 & 5.756 \\
\hline
\end{tabular}

a. Predictors: (Constant), Saluran Distribusi

b. Dependent Variable: Volume Penjualan 


\section{BIDANG MANAJEMEN}

Sedangkan nilai regresi variabel $\mathrm{X}_{2}$ terhadap $\mathrm{Y}$ yang didapatkan dari hasil perhitungan dapat dilihat dalam persamaan sebagai berikut : $\mathrm{Y}=54,792+$ $0,315 X_{2}$. Artinya perubahan pada variabel $X_{2}$ akan diikuti oleh perubahan pada variabel Y secara positif.

\section{Tabel Resume Perhitungan Regresi Variabel $X_{2}$ Terhadap $Y$}

\section{Coefficients $^{\text {a }}$}

\begin{tabular}{|l|r|r|r|r|r|}
\hline \multirow{2}{*}{ Model } & \multicolumn{2}{|c|}{$\begin{array}{c}\text { Unstandardized } \\
\text { Coefficients }\end{array}$} & $\begin{array}{c}\text { Standardized } \\
\text { Coefficients }\end{array}$ & \multirow{2}{*}{$\mathrm{t}$} & \multirow{2}{*}{ Sig. } \\
\cline { 2 - 5 } & \multicolumn{1}{c|}{$\mathrm{B}$} & Std. Error & \multicolumn{1}{|c|}{ Beta } & & \\
\hline 1 (Constant) & 54.792 & 5.929 & & 9.241 & .000 \\
Saluran & .315 & .080 & .371 & 3.955 & .000 \\
Distribusi & & & & & \\
\hline
\end{tabular}

a. Dependent Variable: Volume Penjualan

Hipotesis kedua yang diajukan adalah hipotesis alternatif (Ha) : saluran distribusi berpengaruh secara signifikan terhadap volume penjualan atau dengan kata lain $\mathrm{Ha}=$ koefisien regresi signifikan. Berdasarkan perbandingan $t_{\text {hitung }}$ dan $t_{\text {tabel }}$ diketahui bahwa $t_{\text {hitung }}$ adalah 3, 955 sedangkan $t_{\text {tabel }}$ dengan tingkat signifikasi $5 \%$ dan $\mathrm{df}=\mathrm{N}-2 ; 100-2=1,990$ didapatkan angka 1,990 . perbandingan antara $t_{\text {hitung }}$ dengan $t_{\text {tabel }}$ dapat dikatakan bahwa $t_{\text {hitung }}$ lebih besar dari $t_{\text {tabel. }}$ Artinya Ha diterima dan Ho ditolak atau dapat dikatakan bahwa Saluran Distribusi benar-benar berpengaruh secara signifikan terhadap volume penjualan.

\section{Pengaruh Promosi $\left(\mathrm{X}_{1}\right)$ dan Saluran Distribusi}

$\left(\mathbf{X}_{2}\right)$ terhadap Volume penjualan $(\mathbf{Y})$

Hasil perhitungan dengan menggunakan SPSS 17.0 didapat nilai korelasi ganda variabel $\mathrm{X}_{1}, \mathrm{X}_{2}$ terhadap $\mathrm{Y}$, menunjukan bahwa promosi dan saluran distribusi dapat mempengaruhi volume penjualan dengan besaran nilai adalah 0,770 .

Nilai korelasi ini mempunyai determinasi sebesar 0,593 atau dapat dikatakan volume penjualan dipengaruhi oleh promosi dan saluran distribusi sebesar 59,3\%. Sebagaimana terdapat pada tabel berikut ini.
」IMM UNIKロM

Jurnal Ilmiah Magister Managemen UNIKOM

Tabel Hasil Perhitungan Determinasi Korelasi

\begin{tabular}{|l|c|r|r|r|}
\hline \multicolumn{7}{|c|}{ Model Summary $^{\mathbf{b}}$} \\
\hline Model & R & R Square & $\begin{array}{c}\text { Adjusted R } \\
\text { Square }\end{array}$ & $\begin{array}{c}\text { Std. Error of } \\
\text { the Estimate }\end{array}$ \\
\hline 1 & $.770^{\mathrm{a}}$ & .593 & .585 & 3.974 \\
\hline
\end{tabular}

a. Predictors: (Constant), Saluran Distribusi , Promosi

b. Dependent Variable: Volume Penjualan

\section{Variabel $X_{1}$ dan $X_{2}$ Terhadap $Y$}

Sedangkan nilai regresi variabel $\mathrm{X}_{1}$ dan $\mathrm{X}_{2}$ terhadap $\mathrm{Y}$ yang didapatkan dari hasil perhitungan dapat dilihat dalam persamaan sebagai berikut : $\mathrm{Y}=$ $15,0490,511 X_{1}+0,356 X_{2}$. Artinya perubahan pada variabel $X_{1}$ dan $X_{2}$ akan diikuti oleh perubahan pada variabel $\mathrm{Y}$ secara positif. Sebagaimana terlihat pada tabel dibawah ini.

\section{Tabel Resume Perhitungan Regresi Variabel $\mathrm{X}_{1}$ \& X2 Terhadap Y}

Coefficients $^{\mathrm{a}}$

\begin{tabular}{|rl|r|r|r|r|r|}
\hline \multirow{2}{*}{ Model } & \multicolumn{2}{|c|}{$\begin{array}{c}\text { Unstandardized } \\
\text { Coefficients }\end{array}$} & $\begin{array}{c}\text { Standardized } \\
\text { Coefficients }\end{array}$ & \multirow{2}{*}{$\mathrm{t}$} & \multirow{2}{*}{ Sig. } \\
\cline { 2 - 5 } & \multicolumn{1}{|c|}{$\mathrm{B}$} & Std. Error & \multicolumn{2}{|c|}{ Beta } & & \\
\hline 1 & (Constant) & 15.049 & 5.594 & & 2.690 & .008 \\
& Promosi & .511 & .049 & .677 & 10.423 & .000 \\
& Saluran & .356 & .055 & .419 & 6.459 & .000 \\
& Distribusi & & & & & \\
\hline
\end{tabular}

a. Dependent Variable: Volume Penjualan

Hipotesis ketiga yang diajukan adalah hipotesis alternatif (Ha) : "Promosi dan Saluran Distribusi berpengaruh secara signifikan terhadap Volume Penjualan" atau dengan kata lain $\mathrm{Ha}=$ koefisien regresi signifikan. Berdasarkan perbandingan $t_{\text {hitung }}$ dan $t_{\text {tabel }}$ diketahui bahwa $t_{\text {hitung }}$ untuk Promosi adalah 10,423 dan untuk Saluran Distribusi adalah 6,459, sedangkan $\mathrm{t}_{\text {tabel }}$ dengan tingkat signifikasi $5 \%$ dan $\mathrm{df}=$ $\mathrm{N}-2 ; 100-2=98$ didapatkan angka 1,990 (interpolasi).

Perbandingan antara $t_{\text {hitung }}$ dengan $t_{\text {tabel }}$ dapat dikatakan bahwa $t_{\text {hitung }}$ lebih besar dari $\mathrm{t}_{\text {tabel. }}$. Artinya Ha diterima dan Ho ditolak atau dapat dikatakan bahwa promosi dan saluran distribusi benar-benar berpengaruh secara signifikan terhadap volume penjualan. Pengujian korelasi ganda dilakukan dengan membandingkan antara $\mathrm{F}_{\text {hitung }}$ dengan $\mathrm{F}_{\text {tabel }}$ (Sugiyono, 2005:220). Dengan ketentuan jika $F_{\text {hitung }}$ lebih besar 


\section{BIDANG MANAJEMEN}

daripada $\mathrm{F}_{\text {tabel }}\left(\mathrm{F}_{\text {hitung }}>\mathrm{F}_{\text {tabel }}\right)$ maka Ha ditolak dan Ho diterima. Berdasarkan perhitungan yang dilakukan dengan menggunakan SPSS Versi 17.0 didapatkan data sebagai berikut :

Tabel Resume Uji Anova dan F Test

\begin{tabular}{|r|r|r|r|r|r|}
\multicolumn{8}{|c|}{ ANOVA $^{\mathbf{b}}$} \\
\hline \multicolumn{1}{|c|}{ Model } & $\begin{array}{r}\text { Sum of } \\
\text { Squares }\end{array}$ & df & $\begin{array}{c}\text { Mean } \\
\text { Square }\end{array}$ & F & Sig. \\
\hline $1 \quad$ Regression & 2233.639 & 2 & 1116.819 & 70.728 & $.000^{\mathrm{a}}$ \\
Residual & 1531.671 & 97 & 15.790 & & \\
Total & 3765.310 & 99 & & & \\
\hline
\end{tabular}

a. Predictors: (Constant), Saluran Distribusi , Promosi

b. Dependent Variable: Volume Penjualan

Tabel diatas menunjukan bahwa $F_{\text {hitung }}$ sebesar 70,728 sedangkan $F_{\text {tabel }}$ dengan $\mathrm{dk}$ pembilang $=1$ dan $\mathrm{dk}$ penyebut $=\mathrm{dk}=100-2-1=97$ dengan taraf kesalahan 5\% harga $\mathrm{F}$ tabel ditemukan adalah 3,95 (interpolasi). Dengan demikian harga $F_{\text {hitung }}$ lebih besar dari harga $F_{\text {tabel }}\left(\mathrm{F}_{\text {hitung }}>\mathrm{F}_{\text {tabel }}\right)$. Hal ini menunjukan bahwa Ha diterima dan Ho ditolak. Sehingga dapat disimpulkan bahwa Promosi dan Saluran Distribusi mempunyai pengaruh signifikan terhadap Volume penjualan.

\section{KESIMPULAN}

\section{Kesimpulan :}

Dari hasil penelitian dan pembahsan pada bab-bab sebelumya, dapat disimpulkan hal-hal sebagai berikut :

1. Terdapat pengaruh promosi terhadap volume penjualan pada UMKM di kabupaten Bandung, hal ini didasarkan pada data hasil perhitungan sebagai berikut :

a. Dengan bantuan pengolahan komputer melalui perhitungan SPSS, didapat angka $t_{\text {hitung }}$ sebesar 8,394 sedangkan tabel, dengan taraf (cc) 0,05 $=1,990$. dengan demikian $t_{\text {hitung }}>t_{\text {tabel. }}$. Hal ini menunjukan bahwa promosi berpengaruh secara signifikan terhadap volume penjualan.

b. Bedasarkan hasil perhitungan diperoleh nilai $\mathrm{r} 2=41,8 \%$ yang menggambarkan bahwa $41,8 \%$ dari variabel volume penjualan ditentukan oleh promosi dan termasuk kategori tinggi. Sedangkan sisanya sebesar 58,2\% ditentukan oleh variabel lain.

\section{J I M M U N I K TM \\ Jurnal Ilmiah Magister Managemen UNIKOM}

2. Terdapat pengaruh saluran distribusi terhadap volume penjualan pada UMKM di kabupaten Bandung.

a. Dengan bantuan pengolahan komputer melalui perhitungan SPSS, di dapat angka $t_{\text {hitung }}$ sebesar 3,955 sedangkan $\mathrm{t}$ tabel, dengan taraf (CC) $0,05=1,990$. Dengan demikian $t_{\text {hitung }}>$ $t_{\text {tabel }}$ Hal ini menunjukan bahwa saluran distribusi berpengaruh secara signifikan terhadap volume penjualan.

b. Berdasarkan hasil perhitungan di peroleh nilai $\mathrm{r} 2=13,8 \%$. Hasil tersebut menggambarkan bahwa 13,8 \% dari variabel volume penjualan di tentukan oleh saluran distribusi dan termasuk kategori rendah. Sedangkan sisanya sebesar 86,2\% ditentukan oleh variabel lain.

3. Terdapat pengaruh tingkat saluran distribusi dan promosi secara bersama-sama terhadap volume penjualan pada UMKM di kabupaten Bandung.

a. Berdasarkan hasil perhitungan diperoleh nilai $\mathrm{r} 2=59,3 \%$. Hasil tersebut menggambarkan bahwa 59,3\% dari variabel volume penjualan di tentukan oleh tingkat promosi dan saluran distribusi dan termasuk kategori tinggi. Sedangkan sisanya sebesar $60,7 \%$ ditentukan oleh variabel lain.

b. Adapun persamaan regresi yang diperoleh $\mathrm{Y}=$ $17,049+0,511 X_{1}+0,356 X_{2}$, persamaan regresi tersebut dapat diartikan bahwa setiap kenaikan satu satuan variabel tingkat promosi dan saluran distribusi akan meningkatkan variabel volume penjualan sebesar 0,511 satuan tingkat promosi dan 0,356 satuan saluran distribusi pada konstanta 15,049.

Dengan demikian seluruh hipotesis yang diajukan semuanya diterima. Hal ini dibuktikan dengan harga $F_{\text {hitung }}$ sebesar 70,728 sedangkan $F_{\text {tabel }}$ dengan $\mathrm{dk}$ pembilang $=1$ dan $\mathrm{dk}$ penyebut $=\mathrm{dk}=100-2-1=97$ dengan taraf kesalahan 5\% harga $\mathrm{F}$ tabel ditemukan adalah 3,95 (interpolasi). Dengan demikian harga $\mathrm{F}_{\text {hitung }}$ lebih besar dari harga $\mathrm{F}_{\text {tabel }}\left(\mathrm{F}_{\text {hitung }}>\mathrm{F}_{\text {tabel }}\right)$.

\section{Saran:}

Didasarkan kesimpulan yang dikemukakan diatas, saran yang di kemukakan adalah :

\section{Bagi Pelaku UMKM :}

1. Pelaksanaan kebijakan promosi dan saluran distribusi. Selama di UMKM kabupaten Bandung berhasil dengan baik. Oleh karena 
itu, hendaknya pelaksanaan promosi dan saluran distribusi tetap dipertahankan bahkan harus ditingkatkan.

2. Pemilik UKM di kabupaten Bandung dalam upaya meningkatkan volume penjualan hendaknya menciptakan ide-ide atau solusi inovatif yang lebih baik, sehingga volume penjualan ditingkatkan lebih baik lagi. Misalnya dengan mengadaptasi tokoh popular dalam kemasan, atau nama produk yang unik.

3. Untuk meningkatkan volume penjualan perlunya komunikasi yang lebih antara konsumen dengan pihak perusahaan agar tidak ada kesalahaan dalam pemasaran.

4. Hal lain yang perlu diperhatikan yaitu dalam proses pengiriman pada agen yang kadangkadang mengalami keterlambatan pengiriman dengan demikian perlu pengawasan yang intensif dalam proses produksi dan menambah stock produk agar dalam mengatasi keterlambatan produk yang dibutuhkan konsumen.

\section{Bagi Peneliti Selanjutnya;}

Hasil penelitian menunjukan bahwa promosi dan saluran distribusi berkorelasi signifikan terhadap volume penjualan karenanya:

1. Kajian penelitian dengan metode deskriptif dengan studi analisis yang lebih mendalam mengenai pengaruh promosi dan saluran distribusi terhadap volume penjualan pada sektor usaha lainnya

2. Untuk mengetahui berbagai hal atau faktor yang mempengaruhi voluime penjualan, maka layaknya dilakukan penelitian sejenis dengan mengkaji berbagai variabel lainnya, yaitu daya beli masyarakat, profesi dan jenis pekerjaan serta iklim politik

3. Supaya diketahui secara lebih mendalam mengenai volume penjualan itu sendiri, maka layaknya dilakukan penelitian dengan pendekatan kualitatif supaya dapat menghasilkan pemahaman secara mendalam dan menyentuh pada akar permasalahannya yang dihadapi lembaga dalam mencapai tujuan yang diharapkan .

\section{Bagi Lembaga Pendidikan Perguruan Tinggi}

1. Hendaknya pihak kampus untuk memberikan ruang seluas-luas bagi para peneliti baik peneliti pemula maupun yang sudah ahli sebagai fungsi dari pengembangan ilmu pengetahuan yang sesuai dengan tuntutan jaman, sebagai bahan kajian dan pijakan untuk pengembangan penelitian selanjutnya

2. Memberikan bantuan fasilitas bagi para peneliti, sehingga hasil yang didapatkan menjadi optimal. Sehingga menimbulkan minat yang tinggi bagi insan akademisi.

\section{DAFTAR PUSTAKA}

Aang Munawar dan Bintang Sahala Marpaun Pengaruh Saluran Distribusi Terhadap Volume Penjualan Pada PT. Winner Graments Jurnal Ilmiah Kesatuan Nomor 1 Volume 10, April 2008

Ade Novera 2014 Pengaruh Biaya Promosi Terhadap Penjualan Sepada Motor_Honda di CV. Mitra Makmur Samarinda eJournal Ilmu Administrasi Bisnis, ISSN 2355-5408 Ilmu Admistrasi Bisnis, Fakultas Ilmu Sosial dan Ilmu Politik, Universitas Mulawarman.

Arindra Diesnu Hernomo, Pengaruh Biaya Promosi Dan Biaya Distribusi Terhadap Volume Penjualan Permen Tolak Angin Pada PT. Muncul Mekar Semarang Jurnal Ilmu Administrasi Bisnis Jurusan Administrasi Bisnis Fakultas Ilmu Sosial dan Ilmu Politik Universitas Diponegoro

Aditama.2002. Pengaruh Harga, Promosi, Produk dan Saluran Distribusi terhadap Keputusan Pembelian pada Depo Air Minum Asri”. Skripsi tidak dipublikasikan

Arikunto, Suharsimi. 1999, Prosedur Penelitian Satuan Pendekatan Praktek, Jakarta : Rineka Cipta.

Basu Swastha dan Irawan. 2003. Manajemen Pemasaran. Yogyakarta : Modern Liberty.

Belkaoui, Ahmed Riahi.2007. Teori Akuntasi (penerjemah : Ali Akbar Yulianto dan Krista). Salemba Empat. Jakarta.

Buchari Alma, 2008. Manajemen Pemasaran dan Pemasaran Jasa. Bandung: Alfabeta.

Buchory, Achmad Herry \& Saladin Djaslim. 2010. Manajemen Pemasaran : Edisi Pertama. Bandung: Linda Karya 
Catur, Hana dan Enny.2011. Analisis Pengaruh Marketing Mix Terhadap penjualan Keramik di Kabupaten Bantul Yogyakarta. Jurnal Pemasaran.

Didin Mukodim 2007, Pengaruh Biaya Promosi Dan Biaya Distribusi Terhadap Penjualan Pada PT. Indofood Sukses Makmur, Tbk Jurnal Ilmiah Proceeding PESAT (Psikologi, Ekonomi, Sastra, Arsitek \& Sipil) Vol. 2

Erina Purnamasari 2014 Penerapan Cost-VolumeProfit Analysis Untuk Evaluasi Pencapaian Laba Pada PT Fastfood Indonesia, Tbk Jurnal Fakultas Ekonomi dan Bisnis, Jurusan Akuntansi Universitas Dian Nuswantoro Semarang

Eva Karla, 2010 Pengaruh Saluran Distribusi Terhadap Peningkatan Volume Penjualan Pada PT NUTRICIA INDONESIA SEJAHTERA Jurnal Universitas Gunadarma

Haeruman, H, 2000, Peningkatan Daya Saing UMKM untuk Mendukung Program PEL. Makalah Seminar Peningkatan Daya Saing, Graha Sucofindo, Jakarta.

Hafsah, Mohammad Jafar, 2004, Upaya Pengembangan Usaha Kecil dan Menengah (UKM), Infokop 25, 40-44.

Ignasius Yenglie Moy dan Farah Alfanur 2013 Pengaruh Biaya Promosi Terhadap Volume Penjualan CHEZ MOKA Coffee Shop Jurnal Eproc Manajemen Bisnis Telekomunikasi dan Informatika, Fakultas Ekonomi dan Bisnis, Universitas Telkom

Jurnal Jurusan Pendidikan Ekonomi Universitas Pendidikan Ganesha Singaraja, Indonesia Vol: 4 No: 1 Tahun: 2014

Kotler, Philip dan Kevin Keller. 2009. Manajemen Pemasaran. Edisi Ketiga Belas. Jilid 1. Jakarta : Erlangga.

Kotler, Philip dan Gary Armstrong. 1997. Dasar-dasar Pemasaran. Edisi Bahasa Indonesia. Jilid 1 dan 2. Jakarta : Erlangga.
Kusuma Dewa, Ndaru. 2009. Analisis Pengaruh Kualitas Produk, Daya Tarik Promosi dan Harga Terhadap Minat Beli. Tesis. Universitas Diponegoro. Semarang.

Kuncoro, Mudrajad. 2003. Metode Riset untuk Bisnis dan Ekonomi. Jakarta : Erlangga.

Muhammad Irfan, 2013. Analisis pengaruh distribusi, promosi dan harga terhadap keputusan pembelian konsumen CV. Dargo Utama Palembang : Artikel Publikasi Ilmiah Universitas Sriwijaya Fakultas Ekonomi

Mulyadi,2005. Akutansi Biaya, Aditya Media Yogyakarta.

Poerwadaminta, WJS. 1988. Kamus Besar Bahasa Indonesia, Jakarta : Balai Pustaka

Rangkuti, Freddy. 2009. Strategi Promosi Yang Kreatif dan Analisis Kasus Integrated Marketing Communication. Jakarta: PT. Gramedia Pustaka Utama.

Riduwan. 2007. Pengantar STATISTIKA, untuk Penelitian Pendidikan, Sosial, Ekonomi, Komunikasi, dan Bisnis. Aplikasi SPSS versi 14.0. Bandung: ALFABETA.

Rizky Ardiansyah 2013 Pengaruh Harga, Produk, Dan Promosi Terhadap Volume Penjualan Sepeda Motor Honda Jurnal Ilmu dan Riset Manajemen Volume 1 Nomor 1, Januari 2013 Sekolah Tinggi Ilmu Ekonomi Indonesia (STIESIA) Surabaya

Saladin, Djaslim. Manajemen Strategi dan Kebijakan Perusahaan, Edisi kedua Penerbit Erlangga, Jakarta.2003

Sugiyono, 2008, Metode Penelitian Bisnis, Alfabeta, Bandung.

Santoso, Singgih, 2009, SPSS Statistik Multivariate, Elex Media Komputindo, Jakarta

Tedjakusuma. 2001. Faktor-Faktor yang Mempengaruhi perilaku Konsumen. Jurnal Bisnis dan Ekonomi , Vol. II tahun 2002 
Lely Saida A, 2008. Pengaruh Saluran Distribusi dan Harga Terhadap Volume Penjualan Pada Industri Rumah Tangga Sodok Di Desa Karangrejo Kecamatan Purwosari Kabupaten Pasuruan, Skripsi. Tidak Diterbitkan

Tjiptono, Fandy. 2001. Strategi Pemasaran. Yogyakarta : Andi Offset.

Undang-Undang No. 20 tahun 2008 tentang Usaha Mikro, Kecil, dan Menengah, Jakarta.

Swastha Basu, 2004, "Azas-Azas Marketing”, Edisi Ketiga Yogyakarta: Liberty.

Sofjan Assauri,2004. Managemen Produksi dan Operasi, Dasar Konsep dan Strategi. Rajawali, Jakarta.

Windri Sulistiya Ningrum jurnal nomor 1 volume 02 tahun 2012 Pengaruh Saluran Distribusi dan Harga Jual Terhadap Volume Penjualan Sandal Pada UKM Sandal di Mojokerto.

http://infoukm.wordpress.com/2008/08/ 25 Juli 2015

www.smecda.com/kajian/file/...3.../01T.Syarif.pdf/2 $\underline{8 \text { juli } 2015}$

www.mvsbnplebizinfo/tutorial/isi/ekonomi. $7 \mathrm{htm} / 14$

Agustus 2015

www.mysimplebiz.info/tutoriallisi/ekonomi.8htm/14

$\underline{\text { Agustus } 2015}$

www.mysimplebiz.info/tutoriallisi/ekonomi.20

htm/14 Agustus 2015 